\title{
Neurotransmitter Activation of Inwardly Rectifying Potassium Current in Dissociated Hippocampal CA3 Neurons: Interactions among Multiple Receptors
}

\author{
Deborah L. Sodickson and Bruce P. Bean \\ Department of Neurobiology, Harvard Medical School, Boston, Massachusetts 02115, and Vollum Institute, \\ Oregon Health Sciences University, Portland, Oregon 97201
}

We characterized potassium current activated by G-proteincoupled receptors in acutely dissociated hippocampal CA3 neurons. Agonists for serotonin, adenosine, and somatostatin receptors reliably activated a potassium-selective conductance that was inwardly rectifying and that was blocked by $1 \mathrm{~mm}$ external $\mathrm{Ba}^{2+}$. The conductance had identical properties to that activated by $\mathrm{GABA}_{\mathrm{B}}$ receptors in the same cells. In onehalf of the CA3 neurons that were tested, the metabotropic glutamate agonist $1 S, 3 R$-ACPD also activated inwardly rectifying $\mathrm{Ba}^{2+}$-sensitive potassium current. Activation of the current by serotonin and adenosine agonists occurred with a time constant of $200-700 \mathrm{msec}$ after a lag of $50-100 \mathrm{msec}$; on removal of agonist the current deactivated with a time constant of 1-2 sec after a lag of $200-400 \mathrm{msec}$. These kinetics are similar to $\mathrm{GABA}_{\mathrm{B}}$-activated current and consistent with a direct action of G-protein on the channels. For somatostatin, both activation and deactivation were approximately fourfold slower, probably limited by agonist binding and unbinding. The halfmaximally effective agonist concentrations were $\sim 75 \mathrm{nM}$ for somatostatin, $\sim 100 \mathrm{~nm}$ for serotonin, and $\sim 400 \mathrm{~nm}$ for 2-chloroadenosine. Dose-response relationships had Hill coefficients of 1.2-1.9, suggesting cooperativity in the receptor-tochannel coupling mechanism. At saturating concentrations of agonists, the combined application of baclofen and either somatostatin, serotonin, or 2-chloroadenosine produced effects that were subadditive and often completely occlusive. However, at subsaturating concentrations the effects of baclofen and 2-chloroadenosine were supra-additive. Thus, low levels of different transmitters can act synergistically in activating inwardly rectifying potassium current.

Key words: serotonin; somatostatin; adenosine; baclofen; metabotropic glutamate receptor; $G A B A_{B}$; GIRK
Many neurons have inwardly rectifying potassium channels activated by neurotransmitters acting via G-proteins (Andrade et al., 1986; North et al., 1987; North, 1989). As with G-proteinactivated inward-rectifier potassium (GIRK) channels in cardiac atrial muscle, neuronal GIRK channels probably are activated by the direct binding of $\beta \gamma$ subunits of G-proteins (Reuveny et al., 1994; Wickman et al., 1994; Huang et al., 1995, 1997; Inanobe et al., 1995; Kof uji et al., 1995; Krapivinsky et al., 1995; Nakajima et al., 1996) (see Jan and Jan, 1997).

In many types of neurons, multiple G-protein-coupled receptors activate inwardly rectifying potassium current. The response to the combined application of pairs of transmitters is sometimes no larger than the response to a single transmitter, suggesting shared elements in the coupling pathways used by different receptors (North and Williams, 1985; Andrade et al., 1986; North et al., 1987; Christie and North, 1988). So far, most experiments examining the combined application of agonists have used saturating concentrations of agonists, partly because of the difficulty of controlling low concentrations in brain slice preparations. However, under physiological conditions the stimulation of G-protein-coupled receptors often may involve lower concentra-

\footnotetext{
Received April 20, 1998; revised July 29, 1998; accepted Aug. 3, 1998.

This work was supported by National Institutes of Health (HL35034). We thank Dr. Gabriela Greif for helpful discussion.

Correspondence should be addressed to Dr. Bruce P. Bean, Department of Neurobiology, Harvard Medical School, 220 Longwood Avenue, Boston, MA 02115.

Dr. Sodickson's present address is Volen Center, Brandeis University, 415 South Street, Waltham, MA 02254.

Copyright (C) 1998 Society for Neuroscience $\quad 0270-6474 / 98 / 188153-10 \$ 05.00 / 0$
}

tions of transmitters. In general, such receptors may not be localized in discrete postsynaptic sites exposed to large concentrations of transmitter but may be exposed more often to low levels of transmitters more diff usely released (Hille, 1992; Isaacson et al., 1993; Bunin and Wightman, 1998). It is therefore important to examine interactions between different receptors at low as well as at high concentrations.

Hippocampal pyramidal neurons are likely to be exposed to multiple transmitters, including glutamate, GABA, serotonin (Brown and Zador, 1990; Knowles, 1992), somatostatin (Kohler et al., 1987; Brown and Zador, 1990; Sivilotti and Nistri, 1991), and adenosine (Zetterstrom et al., 1982; Greene and Haas, 1985; Gordon, 1986; Dunwiddie and Diao, 1994). Of these, GABA, serotonin, and adenosine have been found to activate inwardly rectifying potassium current in hippocampal pyramidal neurons (Segal, 1982; Gähwiler and Brown, 1985; Andrade et al., 1986; Trussell and Jackson, 1987; Alzheimer and ten Bruggencate, 1991; Beck et al., 1992; Thompson et al., 1992; Okuhara and Beck, 1994; Lüscher et al., 1997). Somatostatin has not been reported to activate inwardly rectifying potassium current in hippocampal neurons but does so in other neurons (Mihara et al., 1987; Inoue et al., 1988; North, 1989; Tatsumi et al., 1990; Takano et al., 1997) and modulates other currents in hippocampal neurons (Moore et al., 1988). Hippocampal neurons have G-protein-linked metabotropic glutamate receptors that modulate calcium channels (Swartz and Bean, 1992) and that can couple to GIRK channels in heterologous expression systems (Saugstad et al., 1996), but the activation of GIRK channels in native central neurons has not been reported. 
Using a preparation of acutely isolated CA3 pyramidal neurons that allows for the application of transmitter with no metabolism or uptake, we have characterized the activation of inwardly rectifying potassium current by $\mathrm{GABA}_{\mathrm{B}}$, adenosine, serotonin, somatostatin, and metabotropic glutamate receptors. At subsaturating concentrations, $\mathrm{GABA}_{\mathrm{B}}$ and adenosine agonists applied together showed supra-additive effects. Thus, shared elements in receptor-to-channel coupling can produce cooperative effects of multiple transmitters at low concentrations.

\section{MATERIALS AND METHODS}

Preparation of freshly dissociated neurons. Hippocampi from 7- to 12-d-old Long-Evans rats were dissected in ice-cold oxygenated dissociation solution containing (in mM) $82 \mathrm{Na}_{2} \mathrm{SO}_{4}, 30 \mathrm{~K}_{2} \mathrm{SO}_{4}, 5 \mathrm{MgCl}_{2}, 10 \mathrm{HEPES}$, 10 glucose, and $0.001 \%$ phenyl red indicator, $\mathrm{pH}$ 7.4. Slices $(400 \mu \mathrm{m})$ were cut with a tissue chopper and incubated for $9 \mathrm{~min}$ at $37^{\circ} \mathrm{C}$ in dissociation solution containing $3 \mathrm{mg} / \mathrm{ml}$ protease (Type XXIII, Sigma, St. Louis, MO). Then the enzyme solution was replaced with dissociation solution containing $1 \mathrm{mg} / \mathrm{ml}$ trypsin inhibitor and $1 \mathrm{mg} / \mathrm{ml}$ bovine serum albumin, and the slices were allowed to cool to room temperature under an oxygen atmosphere. As cells were needed, slices were withdrawn, and the $\mathrm{CA} 3$ region was dissected out and triturated to release individual cells. Cells were placed in the recording chamber in Tyrode's solution containing (in mM) $150 \mathrm{NaCl}, 4 \mathrm{KCl}, 2 \mathrm{CaCl}_{2}, 2 \mathrm{MgCl}_{2}, 10$ glucose, and 10 HEPES, pH 7.4 with $\mathrm{NaOH}$. Cells were used within $6-8 \mathrm{hr}$ of slice preparation.

CA3 pyramidal neurons were identified morphologically on the basis of size and shape. Cells identified as pyramidal neurons had a large pyramidal-shaped cell body (12-16 $\mu \mathrm{m}$ width, 20-36 $\mu \mathrm{m}$ length) with a thick apical dendritic stump (4-6 $\mu \mathrm{m}$ width, $18-24 \mu \mathrm{m}$ length).

Whole-cell voltage-clamp recordings. Patch pipettes were pulled from $100 \mu \mathrm{l}$ Boralex micropipettes (Dynalab, Rochester, NY). Pipette resistances ranged from 2 to $5 \mathrm{M} \Omega$ when filled with internal solution containing (in mM) $108 \mathrm{KH}_{2} \mathrm{PO}_{4}, 4.5 \mathrm{MgCl}_{2}, 9$ HEPES, 9 EGTA, 14 creatine phosphate (Tris salt), $4 \mathrm{Mg}$-ATP, and $0.3 \mathrm{GTP}$ (Tris salt), pH-adjusted to 7.4 with $135.4 \mathrm{~mm} \mathrm{KOH}$. The creatine phosphate, ATP, and GTP were added to the internal solution to prevent cell dialysis-induced run-down of GTP-dependent responses. Phosphates were added from $10 \times$ concentrated aliquots stored at $-70^{\circ} \mathrm{C}$. To prevent nucleotide hydrolysis, we kept the final internal solution on ice after phosphates were added.

The use of EGTA may have helped in isolating GIRK currents by suppressing additional conductances that have been reported with some of the agonists used, many of which are activated by the entry or release of internal Ca (Alzheimer and ten Bruggencate, 1991; Uneyama et al., 1993; Wakamori et al., 1993; Rainnie et al., 1994; Harata et al., 1996).

Seals were formed, and the whole-cell configuration was obtained in bath Tyrode's solution. Then the cell was bathed by a gravity-driven constant stream of external solution flowing through microcapillary perfusion pipes positioned directly in front of the cell. The perfusion pipes consisted of a linear array of 12 microcapillary tubes, with internal diameters of 200 or $250 \mu \mathrm{m}$, glued together side by side and fed from separate reservoirs. Solutions were changed by moving the perfusion pipes.

External recording solutions consisted of modified Tyrode's solution with 16 or $60 \mathrm{~mm} \mathrm{KCl}$, with $\mathrm{KCl}$ substituted for an equimolar amount of $\mathrm{NaCl}$. Tetrodotoxin (TTX) was included at $2-3 \mu \mathrm{M}$ in all solutions to block sodium currents. All agonists were stored as concentrated aliquots at -70 or $-20^{\circ} \mathrm{C}$ and diluted into the recording solution on the day of the experiment. Whole-cell currents were recorded with an Axopatch 200A patch-clamp amplifier, filtered at $2 \mathrm{kHz}$, digitized at $20-50 \mathrm{KHz}$, and stored by using a Digidata 1200 interface and pClamp6 software (Axon Instruments, Foster City, CA). Membrane potentials were corrected for a liquid junction potential (Neher, 1992) of $-12 \mathrm{mV}$ between the internal solution and Tyrode's solution (in which the current was zeroed before a seal was obtained).

Current-voltage curves. Current-voltage curves were determined by using voltage ramps $100 \mathrm{msec}$ in duration. To smooth the voltage signal, we low-pass-filtered it at $0.5 \mathrm{kHz}$ (four-pole Bessel filter) before applying the signal to the patch-clamp amplifier. The voltage was corrected for the delay resulting from the filtering. Agonist-induced currents were obtained by subtracting ramp currents before and after the application of an agonist.

All statistics are given as the mean \pm SEM.
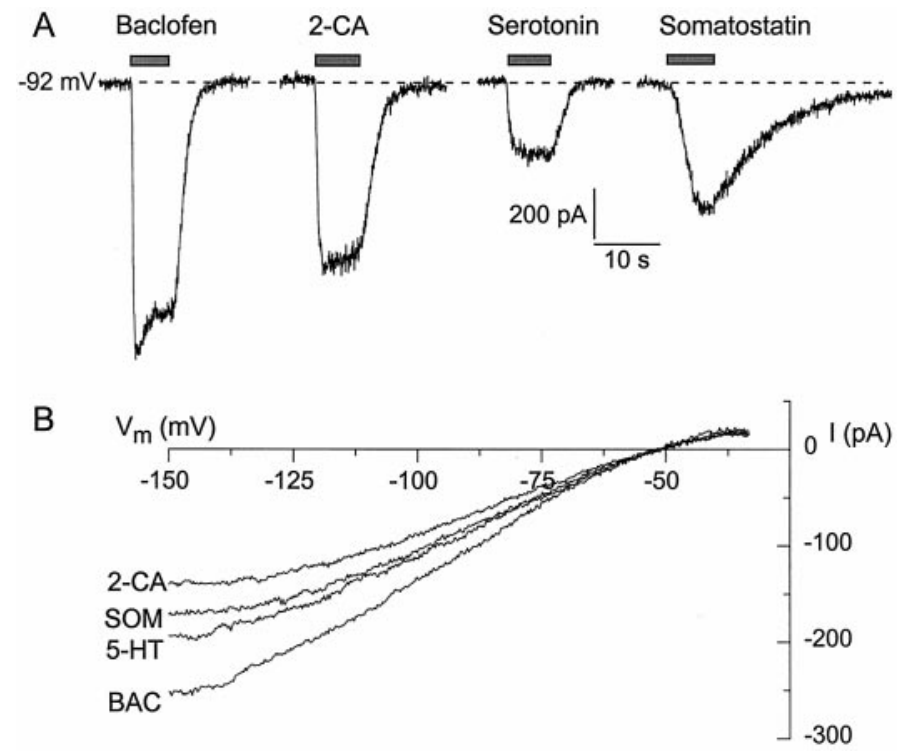

Figure 1. Activation of inwardly rectifying potassium current by multiple agonists in CA3 neurons. A, Agonist-induced currents measured in a single neuron. Shown are inward currents elicited by $6-7 \mathrm{sec}$ applications of $50 \mu \mathrm{M}$ baclofen, $50 \mu \mathrm{M}$ 2-chloroadenosine (2-CA), $30 \mu \mathrm{M}$ serotonin, and $1 \mu \mathrm{M}$ somatostatin applied at a holding potential of $-92 \mathrm{mV}$, with $60 \mathrm{~mm}$ external $\mathrm{K}^{+} . B$, Current-voltage relationships for current elicited by baclofen $(B A C ; 50 \mu \mathrm{M})$, serotonin $(5-H T ; 1 \mu \mathrm{M})$, 2-chloroadenosine (2$C A ; 10 \mu \mathrm{M})$, and somatostatin $(S O M ; 1 \mu \mathrm{M})$ in a single cell, with $16 \mathrm{mM}$ external $\mathrm{K}^{+}$. Current was measured at voltages from -160 to $-30 \mathrm{mV}$, varied by a voltage ramp lasting $100 \mathrm{msec}$. Each trace is the difference between current in an agonist (signal was averaged from 7-12 traces) and control current (signal was averaged from 8-15 traces). Reversal potential for all four agonist responses is $-51 \mathrm{mV}$.

\section{RESULTS}

\section{Transmitter activation of inwardly rectifying potassium current}

In all of the cells that were tested, multiple agonists reliably activated inwardly rectifying potassium current. Figure $1 A$ shows records from a typical dissociated CA3 pyramidal neuron exposed to baclofen, serotonin, the adenosine agonist 2-chloroadenosine, and the peptide hormone somatostatin. All four agonists elicited inward current when they were applied at a holding potential of $-92 \mathrm{mV}$. The current-voltage relationships, measured with voltage ramps from -160 to $-30 \mathrm{mV}$, were identical for the currents elicited by baclofen, serotonin, 2-chloroadenosine, and somatostatin (Fig. 1B). With $16 \mathrm{~mm}$ external potassium the current elicited by all four agonists reversed at $-51 \mathrm{mV}$, close to the predicted reversal potential for a purely potassium-selective conductance $(-56 \mathrm{mV})$, and displayed strong inward rectification.

Activation of inwardly rectifying potassium current was quite reliable for each of the four agonists illustrated in Figure 1. Baclofen induced current in 465 of 466 cells, serotonin in 52 of 56 cells, 2-chloroadenosine in 66 of 67 cells, and somatostatin in 79 of 80 cells. Taking advantage of the ease and rapidity of solution exchange that was possible with the dissociated cell preparation, we determined the dose-response relationship for each agonist. Serotonin at concentrations of $30 \mathrm{~nm}$ and above consistently gave measurable current, and $1 \mu \mathrm{M}$ gave saturating effects. Figure $2 \mathrm{~A}$ shows the dose dependence of currents elicited in a single neuron by various concentrations of serotonin. The dose-reponse relationship could be fit well with a half-maximally effective concen- 


\section{A Serotonin}

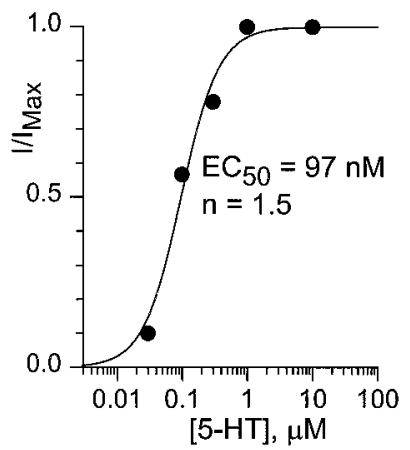

C Somatostatin

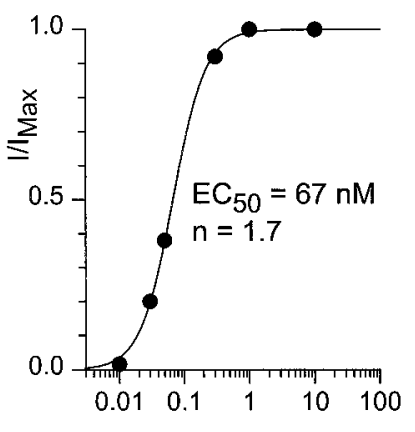

[Som], $\mu \mathrm{M}$
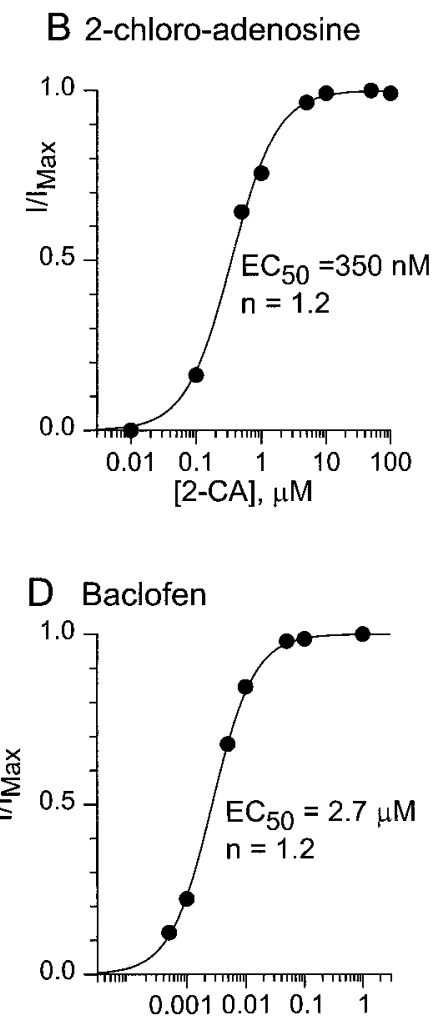

[Baclofen], mM

Figure 2. Dose-response relationship for activation of potassium current $\left(60 \mathrm{~mm}\right.$ external $\mathrm{K}^{+}$) by serotonin $(A)$, 2-chloroadenosine $(B)$, somatostatin $(C)$, and baclofen $(D)$. The dose-reponse for each agonist was determined in a single cell, with responses normalized to the maximal response. The solid lines are the best least-squares fit to the logistic equation, $1 /\left(1+\left(\mathrm{EC}_{50} /[\text { agonist }]\right)^{n}\right)$, where $\mathrm{EC}_{50}$ is the half-maximally effective concentration and $n$ is the Hill coefficient.

tration $\left(\mathrm{EC}_{50}\right)$ of $97 \mathrm{nM}$ and a Hill coefficient of 1.5. In six cells that were tested with serotonin from $1 \mathrm{nM}$ to $10 \mu \mathrm{M}$, the average $\mathrm{EC}_{50}$ was $93 \pm 5 \mathrm{~nm}$ and the average Hill coefficient was $1.3 \pm 0.1$. 2-Chloroadenosine activated substantial potassium current at concentrations $\geq 100 \mathrm{~nm}$ (Fig. $2 B$ ), with an average $\mathrm{EC}_{50}$ of $376 \pm$ $67 \mathrm{~nm}$ and a Hill coefficient of $1.2 \pm 0.1(n=4)$. Somatostatin was the most potent of the four agonists, activating measurable current at concentrations of $10 \mathrm{nM}$ and above, with an average $\mathrm{EC}_{50}$ of $75 \pm 6 \mathrm{nM}(n=7)$. Somatostatin also had the steepest dose-response relationship, with an average Hill coefficient of $1.9 \pm 0.3$. Baclofen had an average $\mathrm{EC}_{50}$ of $3.3 \pm 0.3 \mu \mathrm{M}$ and an average Hill coefficient of $1.06 \pm 0.04(n=9$; Fig. $2 D)$ (see Sodickson and Bean, 1996).

With the rapid application and removal of the agonist, the potassium current induced by baclofen or GABA has sigmoidal activation and deactivation kinetics (Sodickson and Bean, 1996) quite similar to the kinetics of synaptically elicited $\mathrm{GABA}_{\mathrm{B}}$ responses (Otis et al., 1993). The kinetics of potassium current activation and deactivation by serotonin, 2-chloroadenosine, and somatostatin were also sigmoidal, with initial lags followed by rising and falling phases that were fit well by a single exponential. Figure $3 A$ shows an example of current activated by a saturating concentration of 2-chloroadenosine recorded with high time resolution. The agonist was applied and removed in $<20 \mathrm{msec}$ by solenoid movement of the cell between two solutions (Sodickson
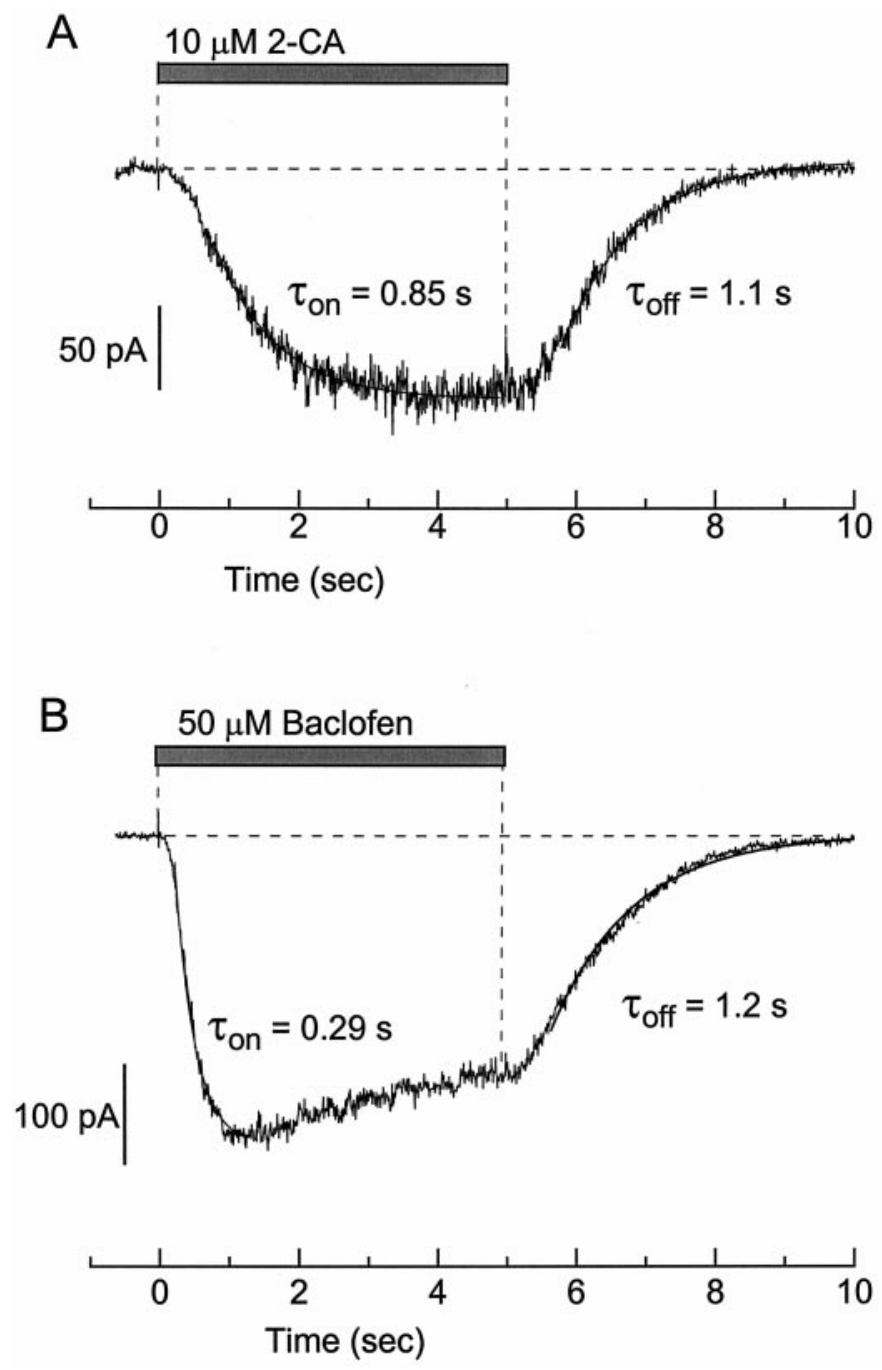

Figure 3. Comparison of kinetics of current elicited by 2-chloroadenosine and baclofen in the same cell. $A$, Application of $10 \mu \mathrm{M}$ 2-chloroadenosine. Superimposed lines are single exponentials with time constants of $0.85 \mathrm{sec}$ (activation) and $1.1 \mathrm{sec}$ (deactivation). $B$. Application of $50 \mu \mathrm{M}$ baclofen. Superimposed lines are single exponentials with time constants of $0.29 \mathrm{sec}$ (activation) and $1.2 \mathrm{sec}$ (deactivation). Holding potential was $-92 \mathrm{mV}$, with $60 \mathrm{~mm}$ external $\mathrm{K}^{+}$.

and Bean, 1996). The general kinetic characteristics of the current induced by 2-chloroadenosine were similar to those of baclofen-activated current in the same cell (Fig. 3B), except that the lag before activation was longer for 2 -chloroadenosine $(\sim 100$ msec) than for baclofen $(\sim 50 \mathrm{msec})$, as was the lag before deactivation $(\sim 600 \mathrm{msec}$ for 2 -chloroadenosine and $\sim 150 \mathrm{msec}$ for baclofen). After the initial lag the rising phase of 2-chloroadenosine-activated current could be fit well by a time constant $(\tau)$ of $0.85 \mathrm{sec}$, slower than the rising phase of baclofenactivated current in the same cell $(\tau=0.29 \mathrm{sec})$. Although baclofen-induced current declined or desensitized slightly after $\sim 1$ sec of exposure, 2-chloroadenosine-induced current did not. On removal of the agonist the main phase of deactivation (after the initial lag) could be fit well by an exponential decline, with kinetics for 2-chloroadenosine $(\tau=1.1 \mathrm{sec})$ very similar to those for baclofen $(\tau=1.2 \mathrm{sec})$.

With all of the agonists the kinetics of activation were dependent on the agonist concentration. As the concentration was 


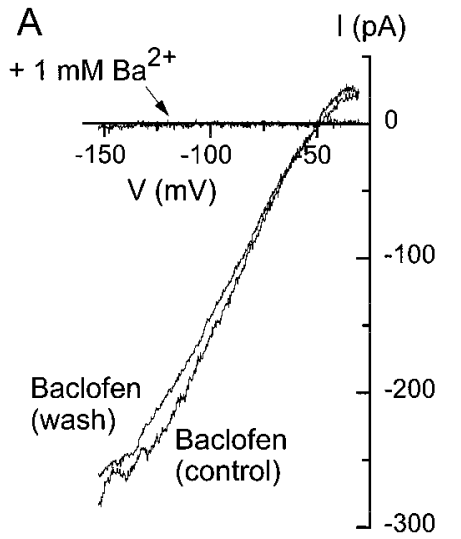

B

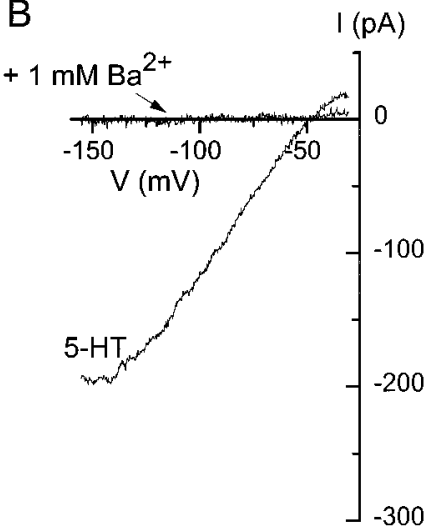

\section{C}

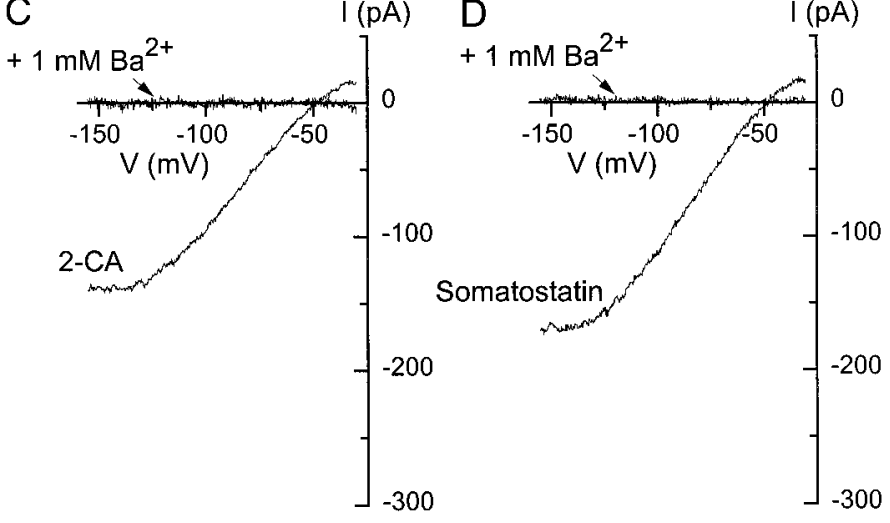

Figure 4. Complete block by $\mathrm{Ba}^{2+}$ of currents elicited by four different agonists in a single cell. $A$, Current elicited by $50 \mu \mathrm{M}$ baclofen with and without $1 \mathrm{mM} \mathrm{Ba}^{2+}$. B, Current elicited by $1 \mu \mathrm{M}$ serotonin with and without $1 \mathrm{mM} \mathrm{Ba}^{2+} . C$, Current elicited by $10 \mu \mathrm{M}$ 2-chloroadenosine with and without $1 \mathrm{~mm} \mathrm{Ba}^{2+}$. D, Current elicited by $1 \mu \mathrm{M}$ somatostatin with and without $1 \mathrm{mM} \mathrm{Ba}^{2+}$. Each trace is the difference between the current in an agonist (signal was averaged from 7-12 traces) and the control current (signal was averaged from 8-15 traces). For determinations with $\mathrm{Ba}^{2+}, 1 \mathrm{mM} \mathrm{BaCl}_{2}$ was present in both the control and agonist-containing solutions; $16 \mathrm{~mm}$ external $\mathrm{K}^{+}$.

raised, the activation kinetics were accelerated until a saturation point was reached. At saturating concentrations the activation time constants were $217 \pm 10 \mathrm{msec}$ for baclofen $(n=10), 487 \pm$ $40 \mathrm{msec}$ for serotonin $(n=25), 686 \pm 60 \mathrm{msec}$ for 2-chloroadenosine $(n=26)$, and $809 \pm 92 \mathrm{msec}$ for somatostatin $(n=37)$. The mean deactivation time constants were $1.1 \pm 0.1$ sec for baclofen $(n=38), 0.95 \pm 0.07 \mathrm{msec}$ for serotonin $(n=25$ cells), $1.9 \pm 0.1 \mathrm{sec}$ for 2 -chloroadenosine $(n=26$ cells $)$, and $8.0 \pm 0.5 \mathrm{sec}$ for somatostatin $(n=33$ cells $)$.

The similarity in current-voltage relationships and in kinetic properties suggests that all four agonists activate similar inwardly rectifying potassium channels and do so via similar coupling pathways. However, several of the agonists have been reported to activate or increase various noninwardly rectifying potassium currents, including calcium-activated potassium current (Wakamori, 1993; Gerber and Gähwiler, 1994; Shirasaki et al., 1994) and M current (Moore et al., 1988). As a further test of whether each agonist activated a single type of conductance under our conditions, we examined sensitivity to external barium, a potent blocker of G-protein-activated inwardly rectifying potassium channels. Currents elicited by baclofen, serotonin, 2chloroadenosine, and somatostatin were all inhibited reversibly by
A

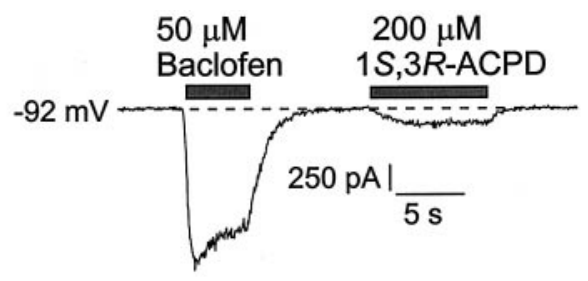

B

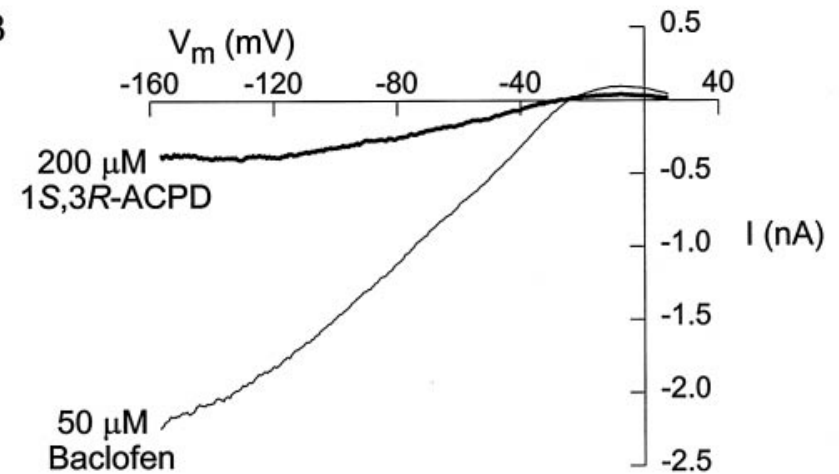

C

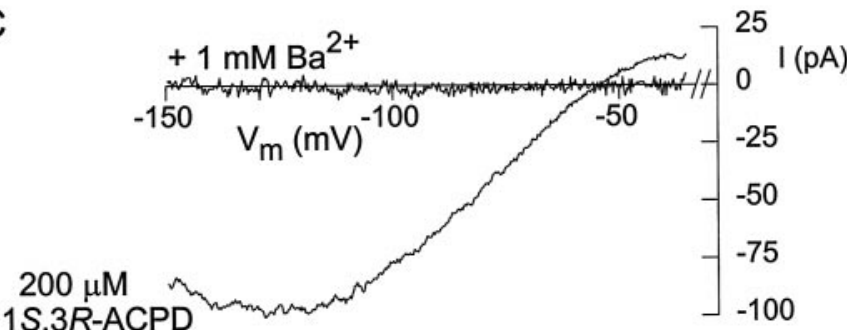

Figure 5. Activation of inwardly rectifying potassium current by $1 S, 3 R$ ACPD. $A$, Effects of $50 \mu \mathrm{M}$ baclofen and $200 \mu \mathrm{M} 1 S, 3 R$-ACPD applied at a holding potential of $-92 \mathrm{mV}$, with $60 \mathrm{~mm}$ external $\mathrm{K}^{+}$. B, Currentvoltage relationships of the current elicited by $1 S, 3 R$-ACPD and baclofen (same cell as in $A$ ). $C$, Block of $1 S, 3 R$-ACPD-activated current by $1 \mathrm{~mm}$ external $\mathrm{Ba}^{2+}$. Each trace is the difference between the current in $1 S, 3 R$-ACPD and the control (signal was averaged from 5-11 traces). For determinations with $\mathrm{Ba}^{2+}, 1 \mathrm{mM} \mathrm{BaCl}_{2}$ was present in both the control and agonist-containing solutions; $16 \mathrm{~mm}$ external $\mathrm{K}^{+}$.

$1 \mathrm{mM} \mathrm{Ba}^{2+}$ applied externally (Fig. 4). In all cases both the inward and outward current was blocked completely ( $n=3$ for each agonist). The completeness and lack of voltage dependence of the $\mathrm{Ba}^{2+}$ block, along with the other similarities, suggest that each transmitter activates the same type of potassium channel and no other conductance.

\section{Activation of inwardly rectifying potassium current by metabotropic glutamate receptors}

The metabotropic glutamate receptor agonist $1 S, 3 R-1$ aminocyclopentane-1,3-dicarboxylic acid ( $1 S, 3 R$-ACPD) was also capable of activating inwardly rectifying potassium current in CA3 pyramidal neurons, although it did so less reliably than the other four agonists. Activation of current by $1 S, 3 R$-ACPD was observed in 22 of 44 neurons tested. Figure $5 A$ shows the activation of current in an individual CA3 neuron by baclofen and $1 S, 3 R$-ACPD, determined with $60 \mathrm{~mm}$ external $\mathrm{K}^{+}$. Figure $5 B$ compares the current-voltage relationships measured from the same neuron. Like the baclofen-activated current, the $1 S, 3 R$ ACPD response was strongly inwardly rectifying and reversed at 


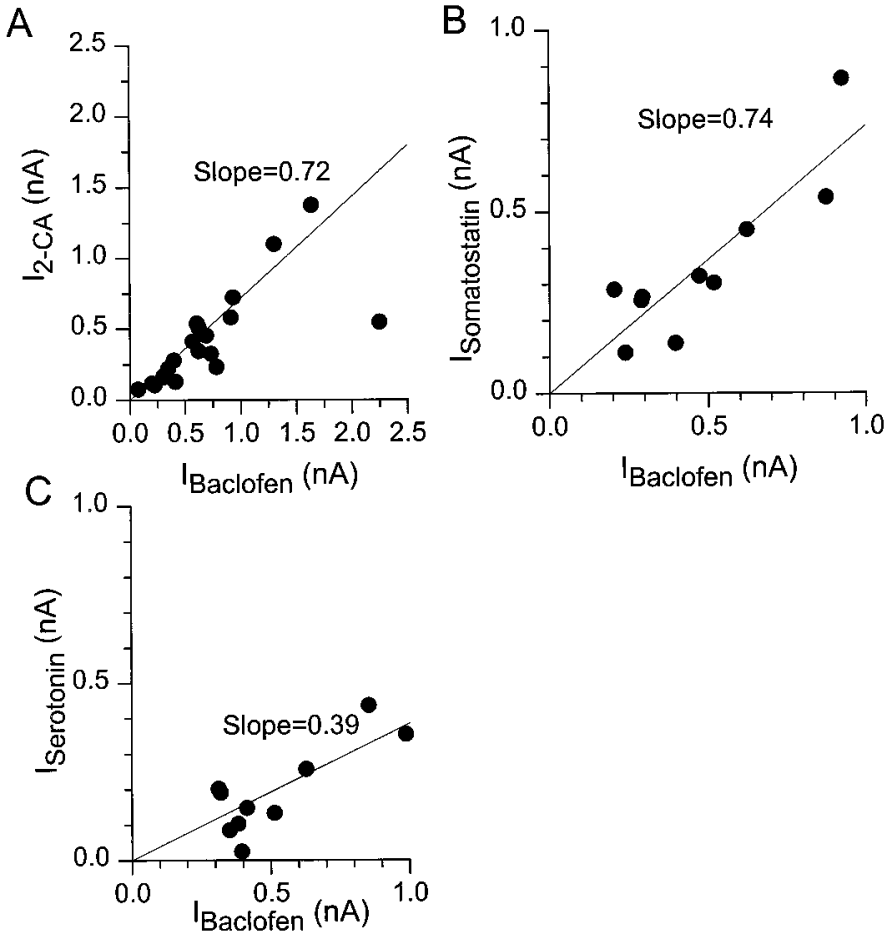

Figure 6. Comparison of the magnitude of potassium current activated by saturating concentrations of baclofen, 2-chloroadenosine, serotonin, and somatostatin. Currents were elicited as in Figure 1 from a holding potential of $-92 \mathrm{mV}$, with $60 \mathrm{~mm}$ external $\mathrm{K}^{+}$. $A$, Current elicited by 2-chloroadenosine $(10-100 \mu \mathrm{M})$ is plotted as a function of that elicited by baclofen $(100 \mu \mathrm{M})$ in the same cell. Each point represents a different cell. $B$, Current elicited by somatostatin $(1-10 \mu \mathrm{M})$ versus that elicited by baclofen $(100 \mu \mathrm{M})$ in the same cell. $C$, Current elicited by serotonin (1-5 $\mu \mathrm{M})$ versus that elicited by baclofen $(100 \mu \mathrm{M})$ in the same cell. The lines are the best fit of a straight line passing through the origin (fit in $A$ has excluded outlying point at $I_{\text {Baclofen }}=2.2 \mathrm{nA}$ ). Correlation coefficients were 0.74 for 2 -chloroadenosine/baclofen, 0.88 for somatostatin/baclofen, and 0.82 for serotonin/baclofen.

$-30 \mathrm{mV}$, close to the predicted potassium equilibrium potential $(-21 \mathrm{mV})$. Figure $5 C$ shows the effects of $1 \mathrm{~mm}$ external barium on the $1 S, 3 R$-ACPD-activated inwardly rectifying current. Both the inward and outward currents were blocked completely. In some neurons, multiple conductances appeared to be affected by $1 S, 3 R$-ACPD, because the current-voltage relationship for $1 S, 3 R$ ACPD-induced current sometimes had an additional component that appeared to reverse near $0 \mathrm{mV}$ and was not inwardly rectifying (data not shown). This could correspond to the nonselective cation conductance reported by Guerineau and colleagues (1995).

We also tested agonists to a variety of other receptors that have been reported to activate inwardly rectifying potassium current in various types of neurons. A number of such agonists failed to elicit responses in the dissociated CA3 pyramidal neurons. Among these were muscarine ( 0 of 15 cells), dopamine ( 0 of 13 cells), platelet-activating factor ( 0 of 6$)$, and the $\mu$-opiate Tyr-DAla-Gly-MePhe-Gly-ol (DAGO) (0 of 3 cells). Noradrenaline produced an inward current at $-92 \mathrm{mV}$ in 4 of 30 neurons; however, the responses were very small, and we were not able to determine clear current-voltage relationships. Neuropeptide Y elicited inward current in 5 of 20 neurons. In three of the five cells the characteristics of the neuropeptide Y-induced current were obviously different from the inwardly rectifying potassium current elicited by other receptors. The development of current was
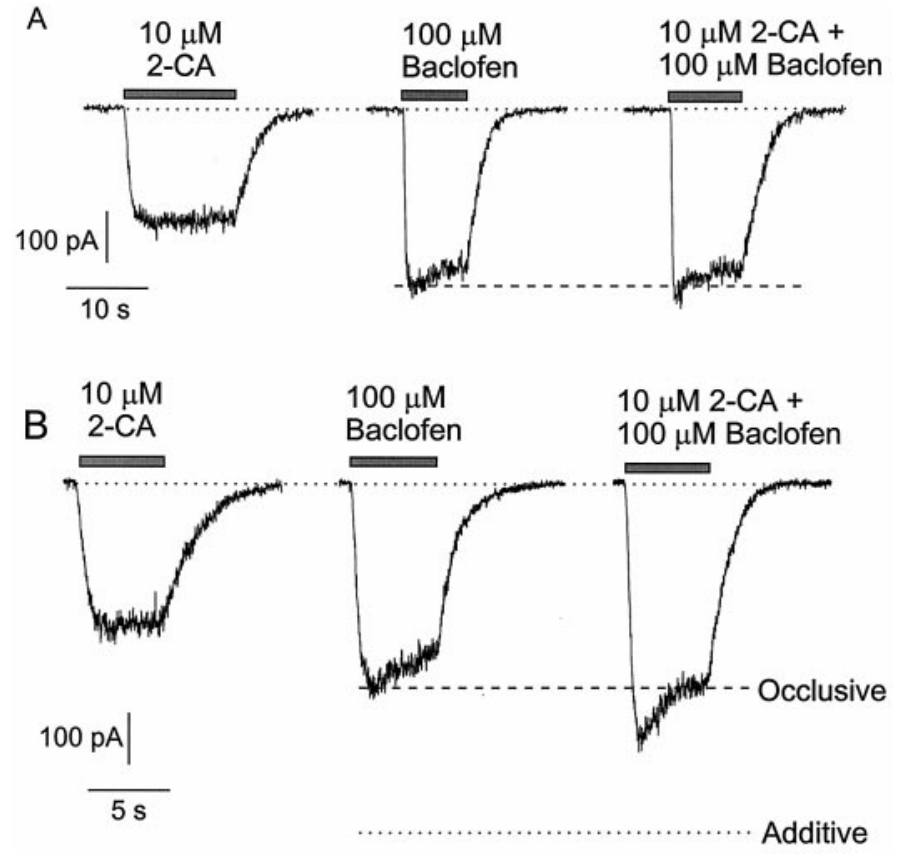

Figure 7. Nonadditivity of current activated by baclofen and 2 -chloroadenosine. $A$, Currents in a neuron with complete occlusion between the effects of baclofen and 2-chloroadenosine. $B$, Responses in a different cell in which there was not complete occlusion. Dashed lines indicate the magnitude of response to baclofen alone. Dotted line indicates the sum of the responses to each agonist applied individually. Conditions are as in Figure 1.

very slow, with current continuing to increase for many seconds, and the current reversed near $0 \mathrm{mV}$, far from the potassium equilibrium potential $(-21 \mathrm{mV}$ under the conditions of the experiment). We did not characterize the neuropeptide Y-induced current further.

\section{Interactions among agonists at saturating concentrations}

We next examined interactions among the four receptors that reliably elicited inwardly rectifying potassium current, using as agonists baclofen, 2-chloroadenosine, serotonin, and somatostatin. In the first set of experiments the agonists were applied at saturating concentrations (from $100 \mu \mathrm{M}$ to $1 \mathrm{~mm}$ baclofen, $10-100$ $\mu \mathrm{M}$ 2-chloroadenosine, 1-5 $\mu \mathrm{M}$ serotonin, and 1-10 $\mu \mathrm{M}$ somatostatin). In cells that were tested with agonists for all four receptors, baclofen almost always elicited the largest current, as in Figure 1. The current elicited by each of the other agonists applied to a given cell was strongly correlated with that elicited by baclofen, as shown in Figure 6 . The current elicited by a saturating concentration of 2-chloroadenosine was typically $\sim 70 \%$ of that elicited by baclofen (Fig. 6A), whereas currents induced by somatostatin and serotonin were $\sim 75$ and $\sim 40 \%$, respectively, of the baclofen-induced current (Fig. $6 B, C$ ). The strong correlation between the magnitude of the currents induced by the different agonists over a wide range of absolute current levels suggests either that levels of expression of the four different receptors are highly correlated or that current levels reflect the expression levels of elements used in common, such as G-proteins or potassium channels.

Andrade et al. (1986) found that simultaneous stimulation of serotonin and $\mathrm{GABA}_{\mathrm{B}}$ receptors in hippocampal pyramidal neurons activated current no larger than that activated by $\mathrm{GABA}_{\mathrm{B}}$ 


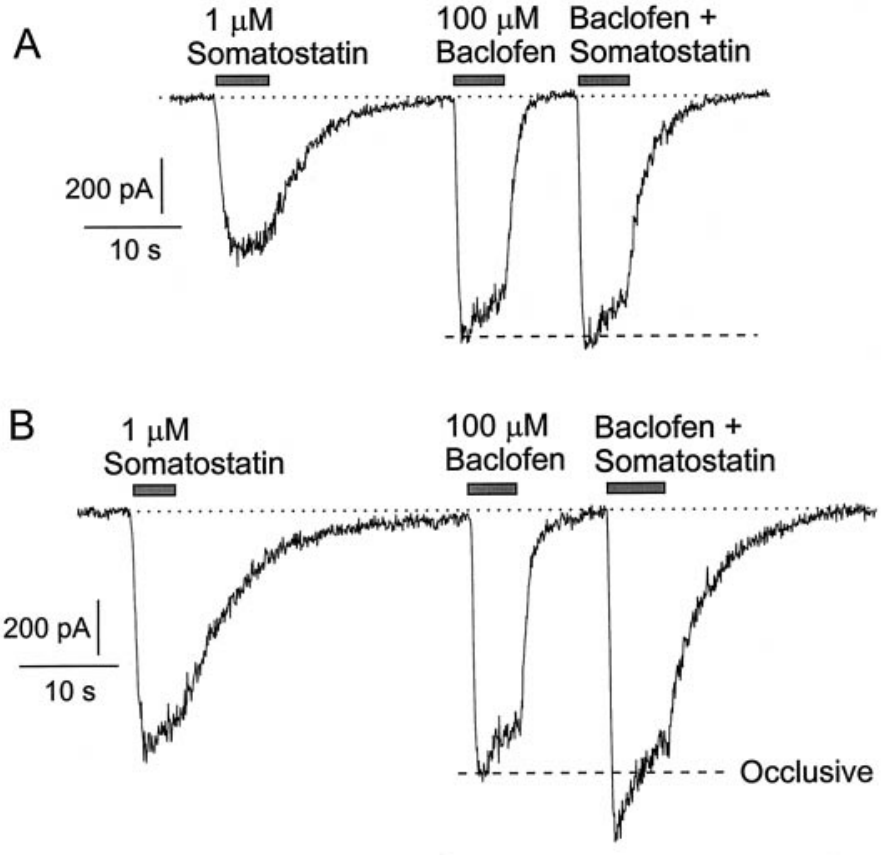

Additive

Figure 8. Nonadditivity of current activated by baclofen and somatostatin. $A$, Currents in a neuron with complete occlusion between the effects of baclofen and somatostatin. $B$, Responses in a different cell in which somatostatin elicited some additional current when applied together with baclofen. Dashed lines indicate the magnitude of response to baclofen alone. Dotted line indicates the sum of the responses to each agonist applied individually. Conditions are as in Figure 1.

receptors alone. We therefore examined the effects of simultaneous exposure to pairs of agonists in single CA3 neurons. First, we compared the activation of inward rectifier potassium current by saturating concentrations of agonists applied separately and together. Figure 7 shows the effects in two different neurons of individual and simultaneous applications of $100 \mu \mathrm{M}$ baclofen and $10 \mu \mathrm{M} 2$-chloroadenosine. For the cell in Figure $7 A$, the response to simultaneous application was completely occlusive with the baclofen response: the magnitude of current elicited with baclofen plus 2-chloroadenosine was identical to that of baclofen applied individually. For the cell in Figure $5 B$, the response to simultaneous application was not completely occlusive, but it was also far less than the sum of the responses to each transmitter alone. In this and other cells the order in which baclofen, 2-chloroadenosine, or baclofen plus 2-chloroadenosine was applied made no difference in the magnitudes of the responses.

Similar results were obtained with paired application of both somatostatin and serotonin with baclofen. In each case in some cells the effects of the combined transmitters were identical with those of baclofen applied alone (Figs. $8 A, 9 A$ ). In other cells some additional current was elicited by the addition of serotonin or somatostatin to baclofen, but the current elicited by the combined transmitters was, with rare exceptions, significantly less than the sum of the currents elicited by each transmitter.

Figure 10 summarizes the degree of additivity for each pair of agonists seen in a number of cells. The degree of additivity was quantified for each cell by calculating the fractional additivity as
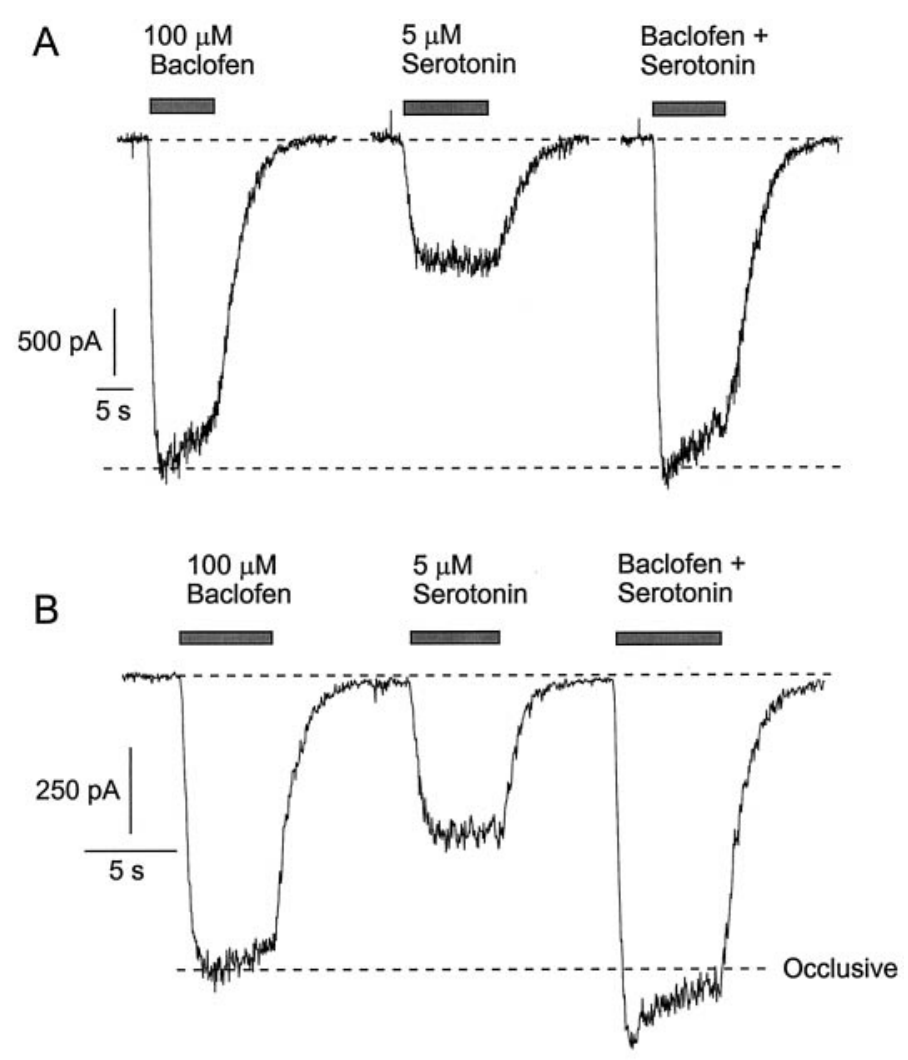

Additive

Figure 9. Nonadditivity of current activated by baclofen and serotonin. $A$, Currents in a neuron with complete occlusion between the effects of baclofen and serotonin. $B$, Responses in a different cell in which serotonin elicited some additional current when applied together with baclofen. Dashed lines indicate the magnitude of response to baclofen alone. Dotted line indicates the sum of the responses to each agonist applied individually. Conditions are as in Figure 1.

$\left(I_{\text {Pair }}-I_{\text {Max }}\right) / I_{\text {Min }}$, where $I_{\text {Pair }}$ is the current elicited by both agonists applied simultaneously, $I_{\mathrm{Max}}$ is the response to the single agonist giving the largest response (almost always baclofen), and $I_{\mathrm{Min}}$ is the response to the other agonist. Thus, 1 corresponds to complete additivity and 0 to complete occlusion of the responses. Collected data were obtained from 20 cells for baclofen/ adenosine experiments, 10 cells for baclofen/somatostatin experiments, and 10 cells for experiments with baclofen/serotonin. The fractional additivity varied from cell to cell. On average, it was smallest for somatostatin $(0.15 \pm 0.03, n=10)$, for which most responses were nearly completely occlusive with baclofen. Both serotonin $(0.53 \pm 0.11, n=10)$ and 2-chloroadenosine (0.36 \pm $0.05, n=20$ ) showed more variability from cell to cell, from completely occlusive to nearly additive.

\section{Interactions among agonists at subsaturating concentrations}

Physiologically, it is likely that the exposure of cells to transmitters such as somatostatin, serotonin, or adenosine usually involves subsaturating concentrations of the transmitters. We therefore explored interactions among different agonist receptors in activating inward rectifier potassium channels at subsaturating concentrations. For this purpose we tested submaximal concentrations of baclofen and 2-chloroadenosine. Agonist concentrations 

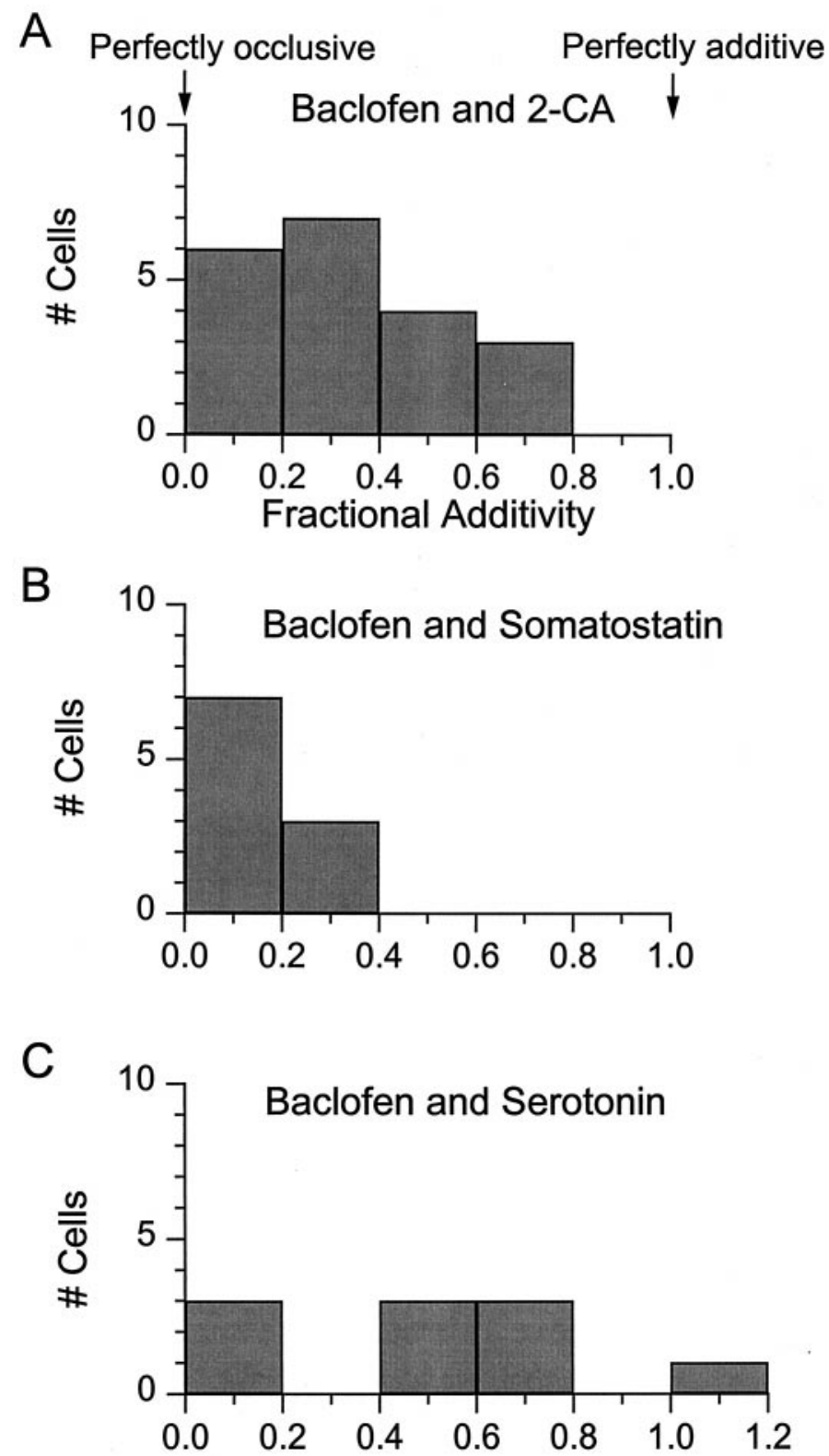

Figure 10. Fractional additivity of the responses to pairs of agonists at saturating concentrations. Fractional additivity of 2-chloroadenosine, somatostatin, and serotonin is expressed as $\left(I_{\text {Pair }}-I_{\text {Max }}\right) / I_{\text {Min }}$, where $I_{\text {Pair }}$ is the current elicited by both agonists applied simultaneously, $I_{\text {Max }}$ is the current elicited by the agonist giving the largest response, and $I_{\text {Min }}$ is the response to the other agonist. A completely additive response has a fractional additivity of 1 , and a completely occlusive response has as a fractional additivity of $0 . A$, Pooled data from 20 neurons tested like those in Figure 7 with baclofen and 2-chloroadenosine. $B$, Pooled data from 10 neurons tested like those in Figure 8 with baclofen and somatostatin. $C$, Pooled data from 10 neurons tested like those in Figure 9 with baclofen and serotonin.

were chosen to be approximately one-third of the $\mathrm{EC}_{50}$. Figure 11 illustrates the responses of a cell to $1 \mu \mathrm{M}$ baclofen and $150 \mathrm{~nm}$ 2-chloroadenosine applied separately and together. The current elicited with simultaneous agonist application was substantially larger (203 pA) than the sum (124 pA) of the currents elicited by baclofen (86 pA) and 2-chloroadenosine (38 pA) applied alone. Thus, in contrast to the subadditivity that was seen with pairs of agonists applied at saturating concentrations, low concentrations

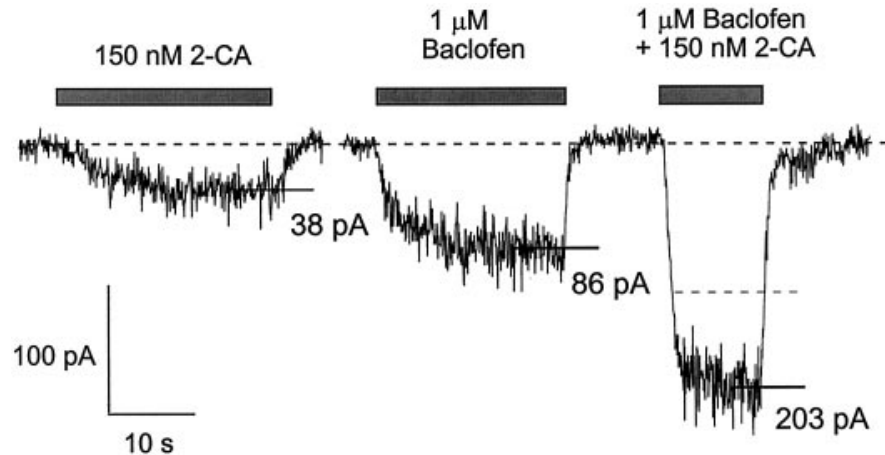

Figure 11. Supra-additivity of responses to baclofen and 2-chloroadenosine at submaximal concentrations. Inward currents were elicited from a holding potential of $-92 \mathrm{mV}\left(60 \mathrm{~mm}\right.$ external $\left.\mathrm{K}^{+}\right)$with individual or simultaneous application of $1 \mu \mathrm{M}$ baclofen and $150 \mathrm{nM}$ 2-chloroadenosine. The dashed line represents the sum of the individual responses to baclofen and 2-chloroadenosine.

applied together gave supra-additive effects. The supra-additivity was quantified as $100 \times\left[I_{\mathrm{Bac}+\text { Aden }}-\left[I_{\mathrm{Bac}}+I_{\text {Aden }}\right]\right] /\left[I_{\mathrm{Bac}}+\right.$ $\left.I_{\text {Aden }}\right]$, the percentage of "extra" current obtained with the pair of agonists. The order in which agonists were applied made no difference in the supra-additivity. Supra-additive responses were obtained in eight of eight cells that were tested (Table 1), with an average supra-additivity of $32 \pm 7 \%$ (range, 12-58\%).

There was cell-to-cell variability in the degree to which there was occlusion at saturating concentrations of transmitters, and there was also cell-to-cell variability in the degree of supraadditivity that was seen with low concentrations. We asked whether there was any correlation between these two properties by testing the same cells for both properties, with 2-chloroadenosine and baclofen applied either alone or together at two different concentration ranges. The results are shown in Table 1. Cells showing more supra-additivity at low concentrations tended to show less complete occlusion at saturating concentrations (sample correlation coefficient, 0.84).

\section{DISCUSSION}

Baclofen, serotonin, somatostatin, and 2-chloroadenosine each reliably activated an inwardly rectifying conductance with high sensitivity to external barium. These similarities, along with the occlusion frequently seen with saturating concentrations of agonists, are consistent with the idea that the different receptors activate the same type of GIRK channel. The molecular composition of G-protein-activated channels in hippocampal neurons is not yet known precisely, but the channels appear to contain GIRK2 subunits, because baclofen- and adenosine-activated current is absent in CA3 neurons from mice lacking the gene for GIRK2 channel subunits (Lüscher et al., 1997) (see also Liao et al., 1996; Slesinger et al., 1996). The single-channel properties and the shape of the current-voltage curve of heterologously expressed GIRK1/GIRK2 channels (Velimirovic et al., 1996) resemble those of native G-protein-gated channels in neurons (Oh et al., 1995; Grigg et al., 1996) (see Fig. 1B). However, although native currents are blocked with high affinity and no apparent voltage dependence by external $\mathrm{Ba}^{2+}$ (see Fig. 4), $\mathrm{Ba}^{2+}$ block of GIRK1/GIRK2 channels occurs with lower affinity and is strongly voltage-dependent (Velimirovic et al., 1996).

Somatostatin has not been reported previously to activate inwardly rectifying potassium currents in hippocampal pyramidal neurons but, rather, to increase voltage-dependent $\mathrm{M}$ current 


\begin{tabular}{|c|c|c|c|c|c|c|c|c|}
\hline Cell & $\begin{array}{l}I_{\mathrm{Bac}} \\
(1 \mu \mathrm{M}) \\
(\mathrm{pA})\end{array}$ & $\begin{array}{l}I_{\text {Aden }} \\
(150 \mathrm{nM}) \\
(\mathrm{pA})\end{array}$ & $\begin{array}{l}I_{\mathrm{Bac}+\text { Aden }} \\
(1 \mu \mathrm{M} \mathrm{Bac}, \\
150 \mathrm{~nm} \text { Aden }) \\
(\mathrm{pA})\end{array}$ & $\begin{array}{l}\text { Supra- } \\
\text { additivity } \\
(\%)\end{array}$ & $\begin{array}{l}I_{\mathrm{Bac}} \\
(100 \mu \mathrm{M}) \\
(\mathrm{pA})\end{array}$ & $\begin{array}{l}I_{\text {Aden }} \\
(10-100 \mu \mathrm{M}) \\
(\mathrm{pA})\end{array}$ & $\begin{array}{l}I_{\mathrm{Bac}+\text { Aden }} \\
(100 \mu \mathrm{M} \mathrm{Bac}, \\
10-100 \mu \mathrm{M} \\
\text { Aden })(\mathrm{pA})\end{array}$ & $\begin{array}{l}\text { Fractional } \\
\text { additivity }\end{array}$ \\
\hline 1 & 93 & 27 & 141 & 18 & 413 & 130 & 413 & 0 \\
\hline 2 & 65 & 25 & 111 & 23 & 206 & 120 & 208 & 0.02 \\
\hline 3 & 62 & 32 & 105 & 12 & 304 & 166 & 334 & 0.18 \\
\hline 4 & 176 & 110 & 339 & 19 & 623 & 344 & 717 & 0.27 \\
\hline 5 & 140 & 94 & 324 & 38 & 690 & 454 & 868 & 0.39 \\
\hline 6 & 112 & 117 & 309 & 35 & 623 & 509 & 907 & 0.56 \\
\hline 7 & 88 & 38 & 199 & 58 & 782 & 232 & 934 & 0.66 \\
\hline 8 & 16 & 21 & 53 & 43 & 75 & 76 & 130 & 0.72 \\
\hline
\end{tabular}

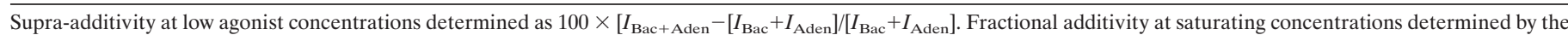
expression $\left[I_{\text {Pair }}-I_{\text {Max }}\right) / I_{\text {Min }}$.

(Moore et al., 1988; Schweitzer et al., 1990). The potassium conductance activated by somatostatin in our experiments is clearly distinct from $\mathrm{M}$ current, because it is prominent at a steady holding potential of $-92 \mathrm{mV}$ at which $\mathrm{M}$ current would not be activated and, unlike $\mathrm{M}$ current, is strongly inwardly rectifying.

\section{Dose-response}

The use of isolated neurons allowed us to determine the sensitivity of hippocampal neurons to well defined concentrations of serotonin, 2-chloroadenosine, and somatostatin. The $\mathrm{EC}_{50}$ for serotonin $(83 \mathrm{~nm})$ is in the range of extrasynaptic serotonin evoked by brief stimuli in other CNS regions (Bunin and Wightman, 1998). The high sensitivity to serotonin is striking, because that determined from hippocampal slice recordings was $\sim 90$-fold lower, with estimated $\mathrm{EC}_{50}$ values of 5-10 $\mu \mathrm{M}$ (Andrade and Nicoll, 1987; Okuhara and Beck, 1994). The lower sensitivity in slice recordings probably reflects the reduction of serotonin concentrations at the neuronal surface by efficient local uptake. A high sensitivity to serotonin $\left(\mathrm{EC}_{50}=30 \mathrm{nM}\right)$ also was seen for the activation of potassium current in dissociated dorsal raphe neurons (Penington et al., 1993).

2-Chloroadenosine, which is approximately equipotent with adenosine at $\mathrm{A} 1$ receptors, had an average $\mathrm{EC}_{50}$ of $380 \mathrm{~nm}$. [The $\mathrm{IC}_{50}$ of $660 \mathrm{~nm}$ for 2-chloroadenosine inhibition of synaptic transmission in slice experiments is not much higher (Dunwiddie et al., 1986), consistent with the lack of uptake or metabolism.] Because adenosine is present in extracellular fluid at bulk concentrations of 140-200 nm (Dunwiddie and Diao, 1994), even basal levels of adenosine may produce significant activation of the current, as previously suggested (Haas and Greene, 1988; Dunwiddie and Diao, 1994). The increased levels of adenosine that are seen with seizure activity and during ischemia (Fowler, 1993) would be even more effective. Basal extracellular GABA also may be high enough to activate GIRK current significantly (see Sodickson and Bean, 1996).

For serotonin, 2-chloroadenosine, and somatostatin the Hill coefficients for the dose-response curve were $>1$, as they are for GABA (Sodickson and Bean, 1996). This suggests cooperativity somewhere in the coupling mechanism. One step in the pathway known to be cooperative is the activation of GIRK channels by $\beta \gamma$ subunits, with reported Hill coefficients between 1.5 and 3 (Ito et al., 1992; Krapivinsky et al., 1995). This step would be in common to all of the different receptors. However, the degree of cooperativity in the overall response might be different according to the exact stoichiometry of receptors, G-proteins, and channels, which must be somewhat different for each case.

\section{Kinetics}

The sigmoidal kinetics of activation and deactivation are consistent with a multi-step process consisting of agonist binding to receptor, receptor activation of G-proteins, and G-protein activation of channels. Deactivation rates of baclofen- and serotoninactivated currents $(\tau \sim 1 \mathrm{sec})$ and 2-chloroadenosine-activated currents $(\tau \sim 2 \mathrm{sec})$ are similar to those of cloned GIRK channels coexpressed with regulators of $\mathrm{G}$ protein signaling (RGS) proteins (Doupnik et al., 1997). RGS proteins accelerate the GTPase activity of $\mathrm{G} \alpha$ subunits, which may be rate-limiting (see Breitwieser and Szabo, 1988; Doupnik et al., 1997), at least for the agonists with the fastest deactivation. The slower deactivation of somatostatin-activated currents $(\tau \sim 8 \mathrm{sec})$ may reflect slower unbinding of this higher-affinity agonist. Interestingly, somatostatin had only slightly higher potency $\left(\mathrm{EC}_{50}=67 \mathrm{nM}\right)$ than seroto$\operatorname{nin}\left(\mathrm{EC}_{50}=97 \mathrm{nM}\right)$ but had an eightfold slower rate of deactivation. Both binding and unbinding rates may be slow for somatostatin, a large molecule that may need to collide with its receptor in a particular conformation.

\section{Metabotropic glutamate receptor activation of inwardly rectifying potassium channels}

Metabotropic glutamate receptors can activate GIRK channels in heterologous expression systems (Saugstad et al., 1996), but such activation has not been seen previously in native central neurons. The inwardly rectifying current activated by $1 S, 3 R$-ACPD that we observed in CA3 neurons was essentially identical to that activated by the other agonists, suggesting that it is carried by similar GIRK channels. From the rapid kinetics, it seems likely that receptor-channel coupling is membrane-delimited, as in other cases of transmitter activation of GIRK channels. Metabotropic glutamate receptors in CA3 neurons also can activate different potassium channels that are not inwardly rectifying and require a diffusible intracellular messenger (Premkumar and Chung, 1995). The activation of calcium-dependent potassium conductances by glutamate receptors (Rainnie et al., 1994; Imanishi et al., 1996) might be minimized in our experiments by the presence of internal EGTA.

Excitatory synaptic activation of potassium current in CA3 neurons has not been reported, even though the stimulation of metabotropic receptors probably requires less glutamate than the 
activation of AMPA receptors (Swartz and Bean, 1992). Possibly metabotropic glutamate receptors are mostly extrasynaptic, as hypothesized for $\mathrm{GABA}_{\mathrm{B}}$ receptors.

\section{Simultaneous exposure to pairs of agonists}

The cooperativity observed in potassium current activation when submaximal concentrations of baclofen and adenosine are applied together indicates interactions at some level of their signaling pathways. The simplest interpretation is that the cooperativity with combined transmitters has the same cause as that for cooperativity with a single transmitter, as reflected by Hill coefficients $>1$ for the dose-response curves. Most likely, individual potassium channels require the binding of multiple $\beta \gamma$ subunits, and individual potassium channels sense a pool of G-proteins that can be activated by multiple receptors.

An important unresolved question is how many different activated G-proteins are accessible to a single $\mathrm{K}$ channel, and vice versa (see Neubig, 1994). At one extreme, receptor-G-proteinchannel complexes might be so spatially restricted that each receptor molecule activates a separate pool of G-proteins and channel molecules. This can be ruled out, because different transmitters then would produce additive responses at both saturating and subsaturating concentrations. At the other extreme, each $\mathrm{K}$ channel may be in a cluster of proteins that includes all possible transmitter receptors as well as G-proteins. This may be closer to the actual situation. In cells with completely occlusive responses at saturating concentrations of transmitters, the same channel molecules apparently can be activated by receptor molecules for multiple transmitters. (The saturation could reflect limiting numbers of G-proteins rather than $\mathrm{K}$ channels, but if so, the same G-protein molecules probably would affect a single pool of $\mathrm{K}$ channel molecules.) Because 2-chloroadenosine, serotonin, and somatostatin typically activated substantially less current than baclofen, some fraction of $\mathrm{K}$ channels apparently can be activated by $\mathrm{GABA}_{\mathrm{B}}$ receptors, but not others. A model consistent with the results in a typical cell is that $\sim 30 \%$ of clusters have only $\mathrm{GABA}_{\mathrm{B}}$ receptors and $\sim 70 \%$ have $\mathrm{GABA}_{\mathrm{B}}$ receptors together with adenosine and somatostatin receptors, of which approximately onehalf also have serotonin receptors. In the uncommon cells in which adding another transmitter to saturating baclofen activated substantial additional current, there must be a fraction of clusters that lack $\mathrm{GABA}_{\mathrm{B}}$ receptors (or have too few $\mathrm{GABA}_{\mathrm{B}}$ receptors to produce maximal activation of $\mathrm{G}$-proteins and $\mathrm{K}$ channels even at saturating baclofen).

There was cell-to-cell variability in the extent of interaction among transmitters at both low and high concentrations. For baclofen and 2-chloroadenosine, greater supra-additivity at low concentrations was moderately correlated with less complete occlusion at saturating concentrations (Table 1). One possible interpretation is that, in cells with the most supra-additivity at low concentrations, the limiting factor within clusters is the number of G-proteins. Less occlusive responses at saturating agonist concentrations and a high degree of cooperativity at low concentrations could be produced in clusters in which potassium channels are in excess of G-proteins and therefore are more sensitive to changes in the numbers of activated G-proteins.

Regardless of its molecular basis, the supra-additivity seen at low concentrations of agonists may be significant physiologically. As already noted, basal extracellular levels of some transmitters in the hippocampus, including GABA and adenosine, may be high enough to produce some activation of inwardly rectifying potassium current in pyramidal neurons. Such effects would be enhanced by cooperativity in the action of multiple transmitters.

\section{REFERENCES}

Alzheimer C, ten Bruggencate G (1991) Postsynaptic inhibition by adenosine in hippocampal CA3 neurons: $\mathrm{Co}^{2+}$-sensitive activation of an inwardly rectifying $\mathrm{K}^{+}$conductance. Pflügers Arch 419:288-295.

Andrade R, Nicoll RA (1987) Pharmacologically distinct actions of serotonin on single pyramidal neurones of the rat hippocampus recorded in vitro. J Physiol (Lond) 394:99-124.

Andrade R, Malenka RC, Nicoll RA (1986) A G-protein couples serotonin and $\mathrm{GABA}_{\mathrm{B}}$ receptors to the same channels in hippocampus. Science 234:1261-1265.

Beck SG, Choi KC, List TJ (1992) Comparison of 5-hydroxytryptamine 1A-mediated hyperpolarization in CA1 and CA3 hippocampal pyramidal cells. J Pharmacol Exp Ther 263:350-359.

Breitwieser GE, Szabo G (1988) Mechanism of muscarinic receptorinduced potassium channel activation as revealed by hydrolysisresistant GTP analogues. J Gen Physiol 91:469-493.

Brown TH, Zador AM (1990) Hippocampus. In: The synaptic organization of the brain (Shepherd GM, ed), pp 346-388. New York: Oxford UP.

Bunin MA, Wightman RM (1998) Quantitative evaluation of 5-hydroxytryptamine (serotonin) neuronal release and uptake: an investigation of extrasynaptic transmission. J Neurosci 18:4854-4860.

Christie MJ, North RA (1988) Agonists at $\mu$-opioid, M2-muscarinic, and $\mathrm{GABA}_{\mathrm{B}}$ receptors increase the same potassium conductance in rat lateral parabrachial neurones. Br J Pharmacol 95:896-902.

Doupnik CA, Davidson N, Lester HA, Kofuji P (1997) RGS proteins reconstitute the rapid gating kinetics of $\mathrm{G} \beta \gamma$-activated inwardly rectifying $\mathrm{K}^{+}$channels. Proc Natl Acad Sci USA 94:10461-10466.

Dunwiddie TV, Diao L (1994) Extracellular adenosine concentrations in hippocampal brain slices and the tonic inhibitory modulation of evoked excitatory responses. J Pharmacol Exp Ther 268:537-545.

Dunwiddie TV, Worth TS, Olsson RA (1986) Adenosine analogs mediating depressant effects on synaptic transmission in rat hippocampus: structure-activity relationships for the N6 subregion. Naunyn Schmiedebergs Arch Pharmacol 334:77-85.

Fowler JC (1993) Changes in extracellular adenosine levels and population spike amplitude during graded hypoxia in the rat hippocampal slice. Naunyn Schmiedebergs Arch Pharmacol 347:73-78.

Gähwiler BH, Brown DA (1985) GABA B $_{\text {r }}$ receptor-activated potassium current in voltage-clamped CA3 pyramidal cells in hippocampal cultures. Proc Natl Acad Sci USA 82:1558-1562.

Gerber U, Gähwiler BH (1994) GABA $_{\mathrm{B}}$ and adenosine receptors mediate enhancement of the $\mathrm{K}^{+}$current, IAHP, by reducing adenylyl cyclase activity in rat CA3 hippocampal neurons. J Neurophysiol 72:2360-2367.

Gordon L (1986) Extracellular ATP: effects, sources, and fate. Biochem J 233:309-319.

Greene RW, Haas HL (1985) Adenosine actions on CA1 pyramidal neurones in rat hippocampal slices. J Physiol (Lond) 366:119-127.

Grigg JJ, Kozasa T, Nakajima Y, Nakajima S (1996) Single-channel properties of a G-protein-coupled inward rectifier potassium channel in brain neurons. J Neurophysiol 75:318-328.

Guerineau NC, Bossu JL, Gähwiler BH, Gerber U (1995) Activation of a nonselective cationic conductance by metabotropic glutamatergic and muscarinic agonists in $\mathrm{CA} 3$ pyramidal neurons of the rat hippocampus. J Neurosci 15:4395-4407.

Haas HL, Greene RW (1988) Endogenous adenosine inhibits hippocampal CA1 neurones: further evidence from extra- and intracellular recording. Naunyn Schmiedebergs Arch Pharmacol 337:561-565.

Harata N, Katayama J, Takeshita Y, Murai Y, Akaike N (1996) Two components of metabotropic glutamate responses in acutely dissociated CA3 pyramidal neurons of the rat. Brain Res 711:223-233.

Hille B (1992) G-protein-coupled mechanisms and nervous signaling. Neuron 9:187-195.

Huang CL, Slesinger PA, Casey PJ, Jan YN, Jan LY (1995) Evidence that direct binding of $\mathrm{G} \beta \gamma$ to the GIRK1 G-protein-gated inwardly rectifying $\mathrm{K}^{+}$channel is important for channel activation. Neuron 15:1133-1143.

Huang CL, Jan YN, Jan LY (1997) Binding of the G-protein $\beta \gamma$ subunit to multiple regions of $\mathrm{G}$-protein-gated inward-rectifying $\mathrm{K}^{+}$channels. FEBS Lett 405:291-298.

Imanishi T, Yamanaka H, Rhee JS, Akaike N (1996) Interaction be- 
tween the intracellular $\mathrm{Ca}^{2+}$ stores in rat dissociated hippocampal neurones. NeuroReport 7:1421-1426.

Inanobe A, Morishige $\mathrm{K}$, Takahashi N, Ito $\mathrm{H}$, Mitsuhiko $\mathrm{Y}$, Takumi T, Nishina H, Takahashi K, Kanaho Y, Katada T, Kurachi Y (1995) G $\beta \gamma$ directly binds to the carboxyl terminus of the G-protein-gated muscarinic $\mathrm{K}^{+}$channel, GIRK1. Biochem Biophys Res Commun 212:1022-1028.

Inoue M, Nakajima S, Nakajima Y (1988) Somatostatin induces an inward rectification in rat locus coeruleus neurones through a pertussis toxin-sensitive mechanism. J Physiol (Lond) 407:177-198.

Isaacson JS, Solis JM, Nicoll RA (1993) Local and diffuse synaptic actions of GABA in the hippocampus. Neuron 10:165-175.

Ito H, Tung RT, Sugimoto T, Kobayashi I, Takahashi K, Katada T, Ui M, Kurachi Y (1992) On the mechanism of G-protein $\beta \gamma$ subunit activation of the muscarinic $\mathrm{K}^{+}$channel in guinea pig atrial cell membrane. J Gen Physiol 99:961-983.

Jan LY, Jan YN (1997) Receptor-regulated ion channels [review]. Curr Opin Cell Biol 9:155-160.

Knowles WD (1992) Normal anatomy and neurophysiology of the hippocampal formation. J Clin Neurophysiol 9:252-263.

Kofuji P, Davidson N, Lester HA (1995) Evidence that neuronal G-protein-gated inwardly rectifying $\mathrm{K}^{+}$channels are activated by $\mathrm{G} \beta \gamma$ subunits and function as heteromultimers. Proc Natl Acad Sci USA 92:6542-6546.

Kohler C, Eriksson L, Davies S, Chan-Palay V (1987) Colocalization of neuropeptide $\mathrm{Y}$ tyrosine and somatostatin immunoreactivity in neurons of individual subfields of the rat hippocampal region. Neurosci Lett 78:1-6.

Krapivinsky G, Krapivinsky L, Wickman K, Clapham DE (1995) G $\beta \gamma$ binds directly to the G-protein-gated $\mathrm{K}^{+}$channel, IKACh. J Biol Chem 270:29059-29062.

Liao YJ, Jan YN, Jan LY (1996) Heteromultimerization of G-proteingated inwardly rectifying $\mathrm{K}^{+}$channel proteins GIRK1 and GIRK2 and their altered expression in weaver brain. J Neurosci 16:7137-7150.

Lüscher C, Jan LY, Stoffel M, Malenka RC, Nicoll RA (1997) G-protein-coupled inwardly rectifying $\mathrm{K}^{+}$channels (GIRKs) mediate postsynaptic but not presynaptic transmitter actions in hippocampal neurons. Neuron 19:687-695.

Mihara S, North RA, Surprenant A (1987) Somatostatin increases an inwardly rectifying potassium conductance in guinea-pig submucous plexus neurones. J Physiol (Lond) 390:335-355.

Moore SD, Madamba SG, Joels M, Siggins GR (1988) Somatostatin augments the M-current in hippocampal neurons. Science 239:278-280.

Nakajima Y, Nakajima S, Kozasa T (1996) Activation of G-proteincoupled inward rectifier $\mathrm{K}^{+}$channels in brain neurons requires association of G-protein $\beta \gamma$ subunits with cell membrane. FEBS Lett 390:217-220.

Neher E (1992) Correction for liquid junction potentials in patch-clamp experiments. Methods Enzymol 207:123-131.

Neubig RR (1994) Membrane organization in G-protein mechanisms. FASEB J 8:939-946.

North RA (1989) Twelfth Gaddum memorial lecture. Drug receptors and the inhibition of nerve cells. Br J Pharmacol 98:13-28.

North RA, Williams JT (1985) On the potassium conductance increased by opioids in rat locus coeruleus neurones. J Physiol (Lond) 364:265-280.

North RA, Williams JT, Surprenant A, Christie MJ (1987) Mu and delta receptors belong to a family of receptors that are coupled to potassium channels. Proc Natl Acad Sci USA 84:5487-5491.

Oh U, Ho Y-K, Kim D (1995) Modulation of the serotonin-activated $\mathrm{K}^{+}$channel by G-protein subunits and nucleotides in rat hippocampal neurons. J Membr Biol 147:241-253.

Okuhara DY, Beck SG (1994) 5-HT1A receptor linked to inwardrectifying potassium current in hippocampal CA3 pyramidal cells. J Neurophysiol 71:2161-2167.

Otis TS, DeKoninck Y, Mody I (1993) Characterization of synaptically elicited $\mathrm{GABA}_{\mathrm{B}}$ responses using patch-clamp recordings in rat hippocampal slices. J Physiol (Lond) 463:391-407.
Penington N, Kelly JS, Fox AP (1993) Whole-cell recordings of inwardly rectifying $\mathrm{K}^{+}$currents activated by 5 -HT1A receptors on dorsal raphe neurones of the adult rat. J Physiol (Lond) 469:387-405.

Premkumar L, Chung SH (1995) Activation of $\mathrm{K}^{+}$channels by stimulation of metabotropic glutamate receptors. NeuroReport 6:765-768.

Rainnie DG, Holmes KH, Shinnick-Gallagher P (1994) Activation of postsynaptic metabotropic glutamate receptors by trans-ACPD hyperpolarizes neurons of the basolateral amygdala. J Neurosci 14:7208-7220.

Reuveny E, Slesinger PA, Inglese J, Morales JM, Iniguez-Lluhi JA, Lefkowitz RJ, Bourne HR, Jan YN, Jan LY (1994) Activation of the cloned muscarinic potassium channel by G-protein $\beta \gamma$ subunits. Nature 370:143-146.

Saugstad JA, Segerson TP, Westbrook GL (1996) Metabotropic glutamate receptors activate G-protein-coupled inwardly rectifying potassium channels in Xenopus oocytes. J Neurosci 16:5979-5985.

Schweitzer P, Madamba S, Siggins GR (1990) Arachidonic acid metabolites as mediators of somatostatin-induced increase of neuronal M-current. Nature 346:464-467.

Segal M (1982) Intracellular analysis of a postsynaptic action of adenosine in the rat hippocampus. Eur J Pharmacol 79:193-199.

Shirasaki T, Harata N, Akaike N (1994) Metabotropic glutamate response in acutely dissociated hippocampal CA1 pyramidal neurones of the rat. J Physiol (Lond) 475:439-453.

Sivilotti L, Nistri A (1991) GABA receptor mechanisms in the central nervous system. Prog Neurobiol 36:35-92.

Slesinger PA, Patil N, Liao YJ, Jan YN, Jan LY, Cox DR (1996) Functional effects of the mouse weaver mutation on G-protein-gated inwardly rectifying $\mathrm{K}^{+}$channels. Neuron 16:321-331.

Sodickson DL, Bean BP (1996) GABA $_{\mathrm{B}}$ receptor-activated inwardly rectifying potassium current in dissociated hippocampal CA3 neurons. J Neurosci 16:6374-6385.

Swartz KJ, Bean BP (1992) Inhibition of calcium channels in rat CA3 pyramidal neurons by a metabotropic glutamate receptor. J Neurosci 12:4358-4371.

Takano K, Yasufuku-Takano J, Kozasa T, Nakajima S, Nakajima Y (1997) Different G-proteins mediate somatostatin-induced inward rectifier $\mathrm{K}^{+}$currents in murine brain and endocrine cells. J Physiol (Lond) 502:559-567.

Tatsumi H, Costa M, Schimerlik M, North RA (1990) Potassium conductance increased by noradrenaline, opioids, somatostatin, and Gproteins: whole-cell recording from guinea pig submucous neurons. J Neurosci 10:1675-1682.

Thompson SM, Haas HL, Gähwiler BH (1992) Comparison of the actions of adenosine at pre- and postsynaptic receptors in the rat hippocampus in vitro. J Physiol (Lond) 451:347-363.

Trussell LO, Jackson MB (1987) Dependence of an adenosine-activated potassium current on a GTP-binding protein in mammalian central neurons. J Neurosci 7:3306-3316.

Uneyama H, Ueno S, Akaike N (1993) Serotonin-operated potassium current in CA1 neurons dissociated from rat hippocampus. J Neurophysiol 69:1044-1052.

Velimirovic BM, Gordon EA, Lim NF, Navarro B, Clapham DE (1996) The $\mathrm{K}^{+}$channel inward rectifier subunits form a channel similar to neuronal G-protein-gated $\mathrm{K}^{+}$channel. FEBS Lett 379:31-37.

Wakamori M, Hidaka H, Akaike N (1993) Hyperpolarizing muscarinic responses of freshly dissociated rat hippocampal CA1 neurones. J Physiol (Lond) 463:585-604.

Wickman KD, Iniguez-Lluhi JA, Davenport PA, Taussig R, Krapivinsky GB, Linder ME, Gilman AG, Clapham DE (1994) Recombinant G-protein $\beta \gamma$ subunits activate the muscarinic-gated atrial potassium channel. Nature 368:255-257.

Zetterstrom T, Vernet L, Ungerstedt U, Tossman U, Jonzon B (1982) Purine levels in the intact rat brain. Studies with an implanted perfused hollow fiber. Neurosci Lett 29:111-115. 